\title{
Pengaruh Model Pembelajaran Extended Triad Level ++ Terhadap Kemampuan Pembuktian Teorema Pada Analisis Real Di Universitas Muhammadiyah Bengkulu
}

\author{
Malito Junizon \\ Program Pascasarjana Pendidikan Matematika Universitas Bengkulu \\ malitojunizon26@gmail.com
}

\begin{abstract}
Abstrak
Tujuan penelitian ini adalah menentukan pengaruh model pembelajaran extended triad level ++ dan self efficacy terhadap kemampuan pembuktian teorema mahasiswa pada analisis real di Universitas Muhammadiyah Bengkulu. Jenis Penelitian adalah penelitian eksperimen dengan desain quasi experimental yang dilaksanakan di Universitas Muhammadiyah Bengkulu pada semester ganjil 2016/2017 dengan populasi penelitian adalah seluruh mahasiswa pendidikan matematika dan sampel penelitian ini adalah mahasiswa pendidikan matematika Semester V. Terdapat dua kelas penelitian yakni satu kelas sebagai kelas eksperimen dan satu kelas sebagai kelas kontrol. Data dianalisis secara kuantitatif dengan menggunakan uji Ancova. Hasil penelitian menunjukkan bahwa ada pengaruh model pembelajaran extended triad level ++ dan self efficacy terhadap kemampuan pembuktian teorema dengan nilai probabilitas $p<$ 0,05 . Selain itu, berdasarkan nilai $r_{\text {square }}$ model pembelajaran extended triad level ++ dan self efficacy memberikan pengaruh sebesar 36,6\% terhadap kemampuan pembuktian teorema dan menunjukkan kemampuan pembuktian teorema mahasiswa yang diajar melalui model pembelajaran Extended Triad Level ++ lebih baik dari pada mahasiswa yang diajar menggunakan model konvensional.
\end{abstract}

Kata Kunci: $\quad$ Model pembelajaran Extended Triad Level ++, Kemampuan pembuktian teorema.

\section{PENDAHULUAN}

Proses pembelajaran matematika di perguruan tinggi membutuhkan kemampuan kognitif tingkat tinggi, seperti kemampuan analisis,sintesis dan evaluasi. Mahasiswa diharapkan mampu untuk bernalar dengan baik dan mengekspresikan hasil penalarannya secara tertulis, sistematis dan ketat (rigorous).

Analisis real merupakan salah satu matakuliah bidang matematika yang cukup ketat dalam memberlakukan system deduktif-aksiomatik. Muatan materi pada analisis real bersifat abstrak, teoritis dan mendalam, yang disusun atas unsur-unsur berupa sifat-sifat, definisi, prinsip, aksioma, postulat dan teorema-teorema. Unsur-unsur yang termuat pada analisis real tersebut merupakan suatu pernyataan matematik yang dirumuskan secara logis yang harus mampu dipahami, dimengerti dan dibuktikan dengan baik sesuai dengan metode pembuktian yang dibenarkan. Karena itu,kemampuan yang dimunculkan dalam analisis real adalah kemampuan dalam melakukan pembuktian.

Menurut Julan Hernadi (2008:1) Pembuktian adalah "serangkaian argument logis yang menjelaskan kebenaran suatu pernyataan”. Sebagaimana menurut Dadang Juandi S, (2008:3) pembuktian adalah "penerapan sejumlah berhingga langkah-langkah logis dari apa yang diketahui (aksioma,prinsip-prinsip atau hasil pembuktian sebelumnya) dengan menggunakan aturan inferensi yang dapat diterima”. Logis berarti semua langkah dan tahapan pembuktian 
merupakan satu kesatuan yang merupakan justifikasi dari langkah sebelumnya. Sehingga semua premis pada setiap deduksi dapat diterima karena sudah dibuktikan atau diberikan sebagai asumsi.

Kegiatan pembuktian pada analisis real berupa pembuktian konjektur dan pembuktian pada teorema. Menurut (Kadir dkk,2008:2) Konjektur adalah "suatu pernyataan yang belum dapat dibuktikan secara matematis, namun memiliki bukti-bukti empiris dalam bentuk kasuskasus dan contoh". Sedangkan teorema adalah suatu pernyataan matematika yang dirumuskan secara logis dan kebenarannya harus dibuktikan.

Berdasarkan hasil identifikasi lembar evaluasi mahasiswa di Universitas Muhammadiyah Bengkulu, dapat diuraikan beberapa kesulitan mahasiswa dalam memahami Analisi Real. Diantara kesulitan itu adalah kesulitan dalam pembuktian teorema. mahasiswa sulit merespon maksud soal yang menyebabkan sulit untuk melanjutkan langkah pembuktian selanjutnya. Kalaupun terdapat sebagian mahasiswa dapat merespon soal dengan baik, namun tetap sulit memulai pembuktian oleh karena tidak dapat mengkonstruksi bukti dan menerapkan teorema dan dalil yang berlaku pada analisis real di dalam mengkonstruksi setiap langkah-langkah logis untuk mencapai solusi dan kesimpulan dari pembuktian.

Identifikasi masalah selanjutnya, dilakukan wawancara terhadap dosen yang mengajar analisis real di universitas muhammadiyah Bengkulu dan universiats Bengkulu, bahwa terdapat kesulitan yang serupa dalam mempelajari analisis real diantaranya mahasiswa belum bisa mengawali proses pembuktian, bingung dari mana pada saat mulai pembuktian, algoritma pembuktian cenderung belum dimengerti,

Kondisi tersebut merupakan implikasi bahwa intuisi pemahaman terhadap suatu konsep yang dimiliki mahasiswa sedikit, mahasiswa tidak dapat menyatakan defenisi dengan bahasanya sendiri,sehingga mahasiwa tidak mengetahui bagaimana menggunakan definisi untuk memperoleh struktur pembuktian secara menyeluruh, concept images untuk mengerjakan pembuktian juga tidak cukup, mahasiswa tidak mengetahui bagaimana memulai pembuktian, membuat konjektur dan memeriksa kebenaran dari konjektur itu, mengembangkan dan mengevaluasi argument dan pembuktian matematika bahkan memilih dan menggunakan jenis metode pembuktian yang tepat.

Kesulitan mahasiswa dalam mempelajari dan memahami analisis real tersebut merupakan implikasi dari proses perkuliahan yang kurang maksimal. Pembelajaran dinilai tidak sesuai dengan karakter dan tujuan yang diharapkan dari analisis real. Pembelajaran dilakukan dengan satu arah, dimana dosen memberikan pembahasan awal materi analisis real, kemudian dilanjutkan dengan pembahasan contoh-contoh soal dan latihan. Proses pembelajaran seperti ini, menjadikan mahasiswa cenderung pasif dan tidak memberikan respon positif terhadap materi yang disampaikan. Kepercayaan diri mahasiswa cenderung tidak terbangun dengan baik. Mahasiswa takut untuk memulai dan mencoba langkah setiap pembuktian. Sikap pesimistis yang dialami mahasiswa terhadap mata kuliah analisis real memberikan beban psikologis dan membuat sugesti negative yang mengakibatkan sulitnya mahasiswa dalam memahami materi analisis real, terlebih lagi memiliki kemampuan pembuktian teorema yang baik.

Untuk memperoleh kemampuan pembuktian teorema yang baik, maka diperlukan suatu model pembelajaran yang tepat dan menjadikan perkuliahan aktif serta berorientasi pada kemampuan pembuktian yang diharapkan. Suatu model yang dapat membangun kepercayaan diri mahasiswa, sehingga analisis real sudah tidak lagi menjadi mata kuliah yang dianggap sulit dan tidak mungkin bisa dikuasai dengan baik oleh mahasiswa, namun analisis real adalah mata 
kuliah yang menyenangkan dan mudah untuk dipahami sehingga terbangun semangat dan motivasi serta kepercayaan diri mahasiswa.

Extended Triad Level ++ adalah model pembelajaran yang tepat dalam menjawab permasalahan kemampuan pembuktian teorema analisis real mahasiswa pendidikan matematika. Model pembelajaran Extended Triad Level ++ merupakan hasil penelitian lanjutan oleh Widada, W. yakni pengembangan teori dan model pembelajaran matematika berbasis Triad untuk mahasiswa analisi real yang dikembangkan berdasarkan teori APOS yang memberikan pelevelan dalam perkembangan tingkat kognitif mahasiswa.

Faktor lain yang perlu menjadi perhatian adalah kepercayaan diri (Self-efficacy) yang dimiliki oleh masing-masing mahasiswa. Kepercayaan diri (Self-efficacy) setiap mahasiswa dinilai dapat memberikan pengaruh positif terhadap kemampuan konjektur. Berawal dari kepercayaan diri, akan terbangun sugesti positif, pola pikir dan reaksi emosional dalam membuat keputusan.

Albert Bandura (Romi kurinawan,2011:29) "Kepercayaan diri (Self-efficacy) adalah pertimbangan subjektif individu terhadap kemampuannya untuk menyusun tindakan yang dibutuhkan untuk menyelesaiakan tugas-tugas khusus yang dihadapi". Okech dan harington (Romi kurniawan,2011:29) menyatakan bahwa "Self-efficacy diyakini sebagai predictor dari kecakapan untuk sukses pada berbagai bentuk prestasi”. Sehingga dari berbagai keterangan diatas, dapat disimpulkan bahwa Self-efficacy mahasiswa dalam memahami dan mempelajari analisis real akan berpengaruh terhadap cara mahasiswa menerima dan memproses informasi serta ketekunan dan kemandirian belajar yang pada akhirya memberikan pengaruh positif terhadap kemampuan konjektur untuk menjadi lebih baik.

Rumusan masalah dalam penelitian ini adalah apakah model pembelajaran Extended Triad Level ++ dan Self-Efficacy berpengaruh terhadap kemampuan pembuktian teorema mahasiswa pada analisis real, apakah terdapat perbedaan kemampuan pembuktian teorema antara mahasiswa yang pembelajarannya menggunakan model Extended Triad Level ++ dengan mahasiswa yang pembelajarannya menggunakan model konvensional.

Manfaat penelitian ini adalah diperolehnya suatu informasi tentang pengaruh model pembelajaran Extended Triad Level ++ dan Self Efficacy terhadap peningkatan kemampuan pembuktian teorema pada Analisi Real yang dapat menjadi pertimbangan bagi dosen yang megajar pada matakuliah yang sama.

Menurut Kadir dkk (2008:2) teorema adalah "suatu pernyataan matematika yang dirumuskan secara logis dan kebenarannya harus dibuktikan". Dalam suatu teorema mungkin terdapat fakta, konsep atau operasi yang saling terkait. Pernyataan suatu teorema biasanya ditulis dalam hubungan implikasi "jika...maka..." atau biimplikasi "jika dan hanaya jika", baik dalam bentuk yang sederhana maupun dalam bentuk yang lebih kompleks. Oleh karena itu suatu teorema memiliki bagian hipotesis yaitu dibelakang kata "jika dan konsekuen yaitu dbelakang kata "maka".

Contoh jika $\left(S_{n}\right)$ suatu barisan yang konvergen ke L maka bagian barisan $\left(S_{k(n)}\right)$ juga konvergen ke L. Pernyataan " $\left(\mathrm{S}_{\mathrm{n}}\right)$ suatu barisan yang konvergen ke L" merupakan hipotesis dan pernyataan bagian barisan $\left(S_{k(n)}\right)$ juga konvergen ke L merupakan konsekuensinya. Pernyataan suatu teorema dapat dibuktikan kebenarannya dengan menggunakan aksiomaaksioma, definisi dan teorema sebelumnya.

Menurut I made arnawa (2007) Kemampuan pembuktian teorema adalah "kemampuan menyusun suatu bukti pernyataan/teorema matematik berdasarkan definisi, prinsip, dan teorema-teorema lainnya, serta menuliskannya dalam bentuk pembuktian lengkap (pembuktian langsung atau tak langsung)". Pembuktian pada dasarnya adalah membuat serangkaian deduksi 
dari asumsi (premis atau aksioma) dan hasil-hasil matematika yang sudah ada (lemma atau teorema) untuk memperoleh hasil-hasil penting dari suatu persoalan matematika. Menurut Molli Wahyuni (2017;136), beberapa indikator kemampuan pembuktian teorema adalah sebagai berikut :

a) Pertama, yaitu mampu mengidentifikasi apa yang menjadi fakta atau yang diketahui dan apa yang akan dibuktikan.

b) Kedua, mampu mengidentifikasi apa yang menjadi kesimpulan dalam pembuktian matematika tersebut.

c) Ketiga, mampu menunjukkan aturan/warrant sebagai hal yang menjembatani fakta, argumen dan kesimpulan. Aturan dalam hal ini yaitu aksioma dan teorema matematika yang sah.

d) Keempat, mampu membuat konjektur sebagai hipotesis dalam pembuktian. Konjektur juga diartikan sebagai membuat dugaan mengenai gagasan utama dalam pembuktian.

e) Kelima, mampu mengevaluasi aturan-aturan penarikan kesimpulan dari proses argumentasi yang logis. Dengan kata lain, susunan argumen dan aturan harus sesuai dengan kaidah inferensi yang sah.

f) Keenam, memilih dan menggunakan metode pembuktian yang tepat sesuai dengan metode-metode pembuktian teorema yang dibenarkan.

Berdasarkan penelitian lanjutan oleh Widada, W. (2009), diperoleh satu level baru dari Triad+. Penelitian tersebut berjudul: Pengembangan Teori dan Model Pembelajaran Matematika Berbasis Triad++ untuk Mahasiswa Analisis Real (Studi di FKIP Universitas Bengkulu). Hasil penelitian tersebut merupakan perkembangan skema yang berbasis Teori APOS pada Analisis Real. Adapun Level Triad++ sebagai berikut: Level Pra-O (Pra-Intra), Level 0 (Intra), Level 1 (Semiinter), Level 2 (Inter), Level 3 (Semitrans), dan Level 4 (Trans). Penelitian ini dilanjutkan oleh Widada, W. (2010) sehingga diperoleh pelevelan yang lebih halus dari triad, yang diberi nama Extended Level Triad++. Extended Level Triad++ ini pelevelannya sebanyak tujuh level yaitu: Level Pra-Intra (Pra-Level 0), Level Intra (Level 0), Level Semiinter (Level 1), Level Inter (Level 2), Level Semitrans (Level 3), Level Trans (Level 4), dan, Level Extended Trans (Level 5).

Dari beberapa pelevelan skema triad di atas, maka pada penelitian ini akan dipakai Extended Level Triad++ dari Widada, W. (2010) yang berdasarkan Teori APOS untuk menganalisis level pemahaman konsep mahasiswa materi analisis real. Adapun karakter setiap level tersebut, dapat dideskripsikan oleh Widada, W. (2010) adalah sebagai berikut :

a) Level Pra-Intra (Pra-Level 0) Seorang individu berada pada level pra-intra hanya dapat melakukan aksi-aksi dan aksi secara terpisah dan tidak mampu mencapai proses maupun objek. Pada penelitian ini seorang siswa masuk dalam level Pra-Intra (Pra-Level 0), bila dalam menyelesaikan masalah jarak dan sudut pada kubus hanya mampu menuliskan halhal yang tidak ada kaitannya dengan penyelesaian soal.

b) Level Intra (Level 0) Seorang individu yang masuk pada level intra, hanya dapat melakukan aksi-proses atau objek secara terpisah, dan tidak dapat membangun hubungan aksi, proses atau objek tersebut. Pada penelitian ini siswa yang masuk dalam level Intra (Level O), bila siswa tersebut dapat menuliskan apa yang diketahui pada soal (belum mampu memahami definisi yang ditanyakan soal) tetapi tidak mampu mengoperasikan atau menentukan langkah penyelesaian. 
c) Level Semiinter (Level 1) Seorang individu yang masuk pada level semiinter, dapat melakukan aksi, proses, objek tetapi mereka hanya mengoordinasikan aksi dan proses pada sifat yang sama. Pada penelitian ini siswa yang masuk dalam level Semiinter (Level 1), bila mahasiswa tersebut dapat menuliskan apa yang diketahui pada soal (mampu menunjukkan definisi yang ditanyakan soal), tetapi belum mampu menentukan langkah penyelesaian untuk menentukan pembuktian teorema ditanyakan.

d) Level Inter (Level 2) Seorang individu yang masuk pada level inter, dapat mengonstruksi keterkaitan aksi-proses-objek beberapa sifat yang terkait, untuk membentuk premature schema. Namun, dalam pembentukan premature schema tersebut tidak menggunakan skema awal yang telah dimiliki sebelumnya (tidak dilakukan retrieval of the previous schema). Pada penelitian ini siswa yang masuk dalam level Inter (Level 2), bila siswa tersebut dapat menuliskan apa yang diketahui pada soal (mampu definisi yang ditanyakan soal), sudah mampu menentukan langkah penyelesaian untuk menentukan pembuktian teorema yang ditanyakan. Tetapi belum mampu atau masih salah dalam penyelesaian karena salah atau tidak menggunakan pengetahuan sebelumnya (misalnya definisi, pembuktian teorema).

e) Level Semitrans (Level 3) Seorang individu yang masuk level semitrans dapat mengonstrksi keterkaitan aksi-proses-objek sehingga terbentuk skema bagian dari skema yang matang (premature schema). Dalam pembentukan premature schema tersebut ada kemungkinan seseorang tersebut menggunakan skema awal (melakukan retrieval of the previous schema). Pada penelitian ini siswa yang masuk level Semitrans (level 3), bila mahasiswa belum dapat menyelesaikan soal dengan benar dan sudah menggunakan skema awal, tapi tidak mampu menjelaskan langkah-langkah penyelesaian.

f) Level Trans (Level 4) Seorang individu yang masuk pada level Trans, dapat membangun keterkaitan antara aksi-aksi, objek-objek, dan skema lain ( melakukan retrieval of the previous schema), sehingga terbentuk suatu skema yang matang (mature schema). Skema tersebut dapat digunakan untuk memecahkan permasalahan yang terkait dengan skema tersebut. Titik (Vertex) dan karakteristik penting dari kematangan dari skema adalah digunakan untuk memutuskan suatu objek masuk dalam skema atau tidak. Pada penelitian ini siswa yang masuk dalam level Trans (Level 4), bila siswa tersebut mampu menyelesaikan soal dengan benar dan mampu menjelasakan langkah penyelesaian, tapi tidak mampu membuat simpulan umum.

g) Level Extended Trans (Level 5) Seorang individu yang masuk pada level Extended Trans, selain berada dalam level trans, individu tersebut dapat membangun struktur baru berdasarkan skema-skema matang yang telah dimilikinya. Pada penelitian ini siswa yang masuk dalam level Extended Trans (Level 5), bila mahasiswa tersebut mampu menyelesaikan soal dengan benar, dan mampu menjelaskan aturan/konsep/teorema atau mampu menjelaskan langkah-langkah penyelesaian permasalahan definisi dan teorema pada materi analisis real. Extended Level Triad ++ ini merupakan perbaikan dari Level Triad ++ yang sifat-sifatnya masih mewarisi sifat-sifat Triad, yaitu hierarkis dan fungsional. Hierarkis, sebab Pra-level 0 termuat dalam Level 0, Level 0 termuat dalam Level 1, Level 1 termuat dalam Level 2, dan seterusnya, yaitu Level k pasti termuat dalam Level $(\mathrm{k}+1)$, untuk $\mathrm{k}=0,1,2,3$. Fungsional, sebab perkembangan skema seseorang hanya akan dipetakan pada tepat satu level.

Dalam sintaks pembelajaran yang akan dilakukan penelitian ini, model pembelajaran Extended Triad Level ++ mengadopsi dari Jurnal Pedidikan Matematika Raflesia Vol.1 No.2 halaman 163-172 pada tulisan Widada, W. (2016) yang berjudul Sintaks Model Pembelajaran 
Matematika Berdasarkan Perkembangan Kognitif Peserta Didik. Pada tulisan tersebut, dikemukakan ada 4 (empat) bentuk sintaks yang dilambangkan dengan C1, C2, C3 dan C4 untuk masing-masing sintaks. Secara garis besar sintaks tersebut adalah a. Pendahuluan; b. Kegiatan Inti: (1) Fase pemberian masalah yang sesuai dengan skema peserta didik, (2) Fase berpikir, (3) Fase berpasangan, (4) Fase eksplorasi, (5 Fase diskusi hasil eksplorasi, (6) Fase kesimpulan, dan diakhiri dengan c. Penutup. Widada, W. $(2016,166)$.

\section{b. Self Efficacy}

Apa definisi atau pengertian self efficacy? dan apa pula indikatornya? Bandura (1994) mendefinisikan self-efficacy sebagai berikut:

"Perceived self-efficacy is defined as people's beliefs about their capabilities to produce designated levels of performance that exercise influence over events that affect their lives. Self-efficacy beliefs determine how people feel, think, motivate themselves and behave. Such beliefs produce these diverse effects through four major processes. They include cognitive, motivational, affective and selection processes".

Menurut Bandura sebagaimana dikutip oleh Siagian (2004:71-81), Self efficacy merupakan "suatu bentuk kepercayaan yang dimiliki seseorang terhadap kapabilitas masing-masing untuk meningkatkan prestasi kehidupannya. Self efficacy dapat berupa bagaimana perasaan seseorang, cara berpikir, motivasi diri, dan keinginan memiliki terhadap sesuatu".

Keberadaan self efficacy pada diri seseorang akan berdampak pada empat proses, yaitu: 1. Proses kognitif

Pengaruh self-efficacy pada proses kognitif dapat timbul dalam berbagai format. Banyak perilaku manusia, dengan menggunakan tujuan, diatur dengan pemikiran sebelumnya dalam mewujudkan tujuan. Pengaturan tujuan individu dipengaruhi oleh penaksiran individu terhadap kapabilitas yang dimilikinya.

2. Proses motivasi.

Kepercayaan diri terhadap efficacy memainkan kunci dalam pengaturan diri terhadap motivasi. Motivasi individu banyak ditimbulkan melalui proses kognitif. Orang-orang memotivasi dirinya sendiri dan mengarahkan tindakannya dengan melalui berbagai latihan. Mereka percaya terhadap apa yang mereka lakukan dan selalu mengantisipasi adanya hasil tindakan yang prospektif. Mereka akan mengatur tujuan yang dimilikinya dan merencanakan latihan-latihan sebelum melakukan tindakan dengan mendesainnya sesuai nilai-nilai masa depan.

3. Proses afektif.

Orang-orang percaya terhadap pengaruh kapabilitasnya dalam mengatasi stress dan depresi dalam menghadapi ancaman atau situasi yang sulit, seperti terhadap motivasi dalam dirinya. Dengan adanya self efficacy, seseorang akan lebih mampu mengatasi segala persoalan yang mengancam keberadaannya.

4. Proses seleksi.

Melalui kepercayaan diri terhadap kapabilitas yang dimilikinya, maka seseorang cenderung bertindak selektif atau melakukan pemilihan terhadap pencapaian tujuan hidupnya. Manusia akan memilih pemecahan masalah dan pencapaian tujuan sesuai kapabilitas yang dimilikinya. Seseorang yang meragukan kapabilitas yang dimilikinya akan cenderung mempunyai perasaan malu untuk mengatasi kesulitan-kesulitan yang dimiliki, termasuk dalam mengatasi ancaman yang datang padanya. Mereka mempunyai tingkat aspirasi yang rendah 
dan komitmen yang dimilikinya terhadap suatu hal lemah. Dalam menghadapi segala permasalahan, mereka cenderung untuk selalu menghindar. Mereka akan lebih mudah mengalami stres dan depresi.

Menurut Bandura (1994), indikator dari self efficacy adalah sebagai berikut:

1. Keyakinan untuk dapat memecahkan beragam permasalahan,

2. Keyakinan untuk dapat menyelesaikan masalah berkaitan dengan orang lain,

3. Kemampuan untuk menyelesaikan masalah dengan solusi yang benar

\section{METODE PENELITIAN}

Jenis penilitian ini adalah penelitian Eksperimen dengan desain Quasi Eksperimental Research untuk mengungkap hubungan sebab akibat antar variable. Populasi dalam penelitian ini adalah seluruh mahasiswa pendidikan Matematika Univeristas Muhammadiyah Bengkulu dan sampel penelitian Mahasiswa Semester V. Untuk memperoleh data dalam penelitian ini digunakan beberapa instrument pengumpulan data yakni lembar tes kemampuan pembuktian teorema dan lembar tes Self efficacy. Data diperoleh dengan melakukan tes awal dan tes Self efficacy pada setiap kelas eskperimen dan kelas kontrol, yang kemudian masing-masing kelas diberikan treatment yang berbeda hingga pada akhirnya dilakukan tes akhir kemampuan pembuktian teorema.

\section{HASIL DAN PEMBAHASAN}

Berdasarkan analisis data hasil tes awal kemampuan pembuktian teorema,diperoleh data sebagai berikut :

Tabel 1

Nilai Tes Awal Kemampuan Pembuktian Teorema

\begin{tabular}{|l|c|c|c|}
\hline \multirow{2}{*}{ Kelas Penelitian } & \multicolumn{3}{|c|}{ Kemampuan Pembuktian } \\
\cline { 2 - 4 } & Min & Max & Mean \\
\hline Ekperimen & 22 & 55 & 38,94 \\
\hline Kontrol & 18 & 55 & 30,94 \\
\hline
\end{tabular}

Setelah dilakukan perlakuan dengan menggunakan model pembelajaran Extended triad level ++ maka diperoleh data kemampuan pembuktian teorema sebagai berikut:

Tabel 2

Nilai Tes Kemampuan Pembuktian Teorema

\begin{tabular}{|l|c|c|c|c|}
\hline \multirow{2}{*}{ Kelas Penelitian } & \multicolumn{4}{|c|}{ Kemampuan Pembuktian Teorema } \\
\cline { 2 - 5 } & Min & Max & Mean & $\begin{array}{c}\text { Std. } \\
\text { Deviation }\end{array}$ \\
\hline Ekperimen & 55 & 93,5 & 78,75 & 8,7 \\
\hline Kontrol & 50 & 83 & 67,59 & 7,6 \\
\hline
\end{tabular}

Tabel 1 dan 2, menunjukkan bahwa tedapat peningkatan kemampuan pembuktian teorema mahasiswa setelah diberikan perlakuan dengan model Extended triad level ++ yang memberikan makna bahwa terdapat pengaruh yang signifikan antara model pembelajaran Extended triad level ++ terhadap kemampuan pembuktian teorema mahasiswa. Tabel 2 juga 
memberikan informasi bahwa terdapat perbedaan rata-rata kemampuan pembuktian teorema antara kelas eksperimen yang diajar menggunakan model Extended triad level ++ dan kelas kontrol yang diajar menggunakan model biasa (konvensional). Pada kelas eskperimen rata-rata kemampuan pembuktian teorema mahasiswa 78,75 sedangkan pada kelas kontrol 67,59.

Berdasarkan Analisis uji hipotesis dengan Ancova menunjukkan nilai sig $<0.05$ dengan nilai $\mathrm{F}=27.666$ terdapat pengaruh model pembelajaran extended triad level ++ terhadap kemampuan pembuktian teorema analisis real dengan mengontrol Self efficacy. Besarnya pengaruh model Extended triad level ++ adalah 36,6 \%. Analisis pengaruh Self efficacy terhadap kemampuan diperoleh nilai sig $<0.05$ dengan nilai $\mathrm{F}=10.588$ yang berarti terdapat pengaruh Self efficacy terhadap kemampuan pembuktian teorema mahasiswa pendidikan matematika dan besarnya pengaruh Self efficacy adalah $18,1 \%$. Selanjutnya untuk mengetahui perbedaan kemampuan pembuktian teorema kelas eksperimen dan kelas kontrol maka diperoleh nilai sig $<0.05$ pada $\mathrm{F}=27.666$ dan pada table descriptive statistics diperoleh mean kelas eksperimen 78,75 dan mean kelas kontrol 67,59 serta pada table mean difference menunjukkan terdapat perbedaan yang signifikan kemampuan pembuktian teorema antara mahasiswa yang pembelajarannya menggunakan model Extended triad level ++ dengan mahasiswa yang pembelajarannya menggunakan model pembelajaran konvensional dengan mengontrol Self Efficacy. Besarnya perbedaan kemampuan pembuktian teorema adalah sebesar $11,113 \%$.

\section{SIMPULAN}

1) Terdapat pengaruh model pembelajaran Extended triad level ++ terhadap kemampuan pembuktian teorema mahasiswa. Besar pengaruh model pembelajaran Extended triad level ++ terhadap kemampuan konjektur sebesar 36,6\%

2) Terdapat pengaruh Self efficacy terhadap kemampuan pembuktian teorema mahasiswa. Besar pengaruh Self efficacy terhadap kemampuan pembuktian teorema sebesar 18,1\%

3) Terdapat perbedaan kemampuan pembuktian teorema antara mahasiswa yang pembelajarannya menggunakan model pembelajaran Extended triad level ++ dan mahasiswa yang pembelajarannya menggunakan model konvensional dengan mengontrol Self efficacy. Besarnya perbedaan kemampuan konjektur adalah 11,113\%.

\section{Daftar Pustaka}

Dadang Juandi. 2008. Pembuktian, penalaran, Dan komunikasi matematika, FMIPA:UPI

Dickerson, D. S. (2008). High School Mathematics Teachers'Understandings of the Purposes of Mathematical Proof, Disertasi pada Syracuse University

Elah Nurlaelah \& Utari Sumarmo, 2010. Matematika. Kajian Hasil-hasil Penelitian yang Berkaitan dengan teori APOS dan Kreativitas Bandung : UPI

Julan Hernadi. 2008. Motode Pembuktian Dalam Matematika.Yogyakarta :UAD

Kadir dkk (2008) Contoh-contoh teknik pembuktian dalam matematika, UPI

Kurnia Eka Lestari (2015). Analisis Kemampuan Pembuktian Matematis Mahasiswa Menggunakan Pendekatan Induktif-Deduktif Pada Mata Kuliah Analisis Real. Jurnal Unma Banten No. 17 Vol. 1 September 2015 
I Made Arnawa. 2007. Mengembangkan Kemampuan Mahasiswa dalam Memvalidasi Bukti pada Aljabar Abstrak melalui Pembelajaran Berdasarkan Teori APOS. Jurnal Matematika dan Sains, Juni 2009, vol. 14 no. 2, 64

Ika Yuniawati. ( ) hubungan self efficacy mahasiswa terhadap hasil belajar matematika pada penerapan model students teams achievement division (stad) dan model investigasi kelompok (ik) . Prodi Teknik Informatika. politeknik negeri banyuwangi

Lenny. 2015. Pola Pembelajaran Konvensional. Diakses Dari: http:// lenny lennoy.blogspot.com/2015/04/pola-pembelajaran-konvensional_21. html [06 Agustus 2015].

Romi Kurniawan (2011) Pengaruh Self-efficacy dan motivasi belajar mahasiswa terhadap kemandirian belajar mata kuliah analisis laporan keuangan pada mahasiswa program studi pendidikan akutansi angkatan 2008. Fakultas ilmu social dan ekonomi , UNY

Risnanosanti. (2015). Self Efficacy mahasiswa terhadap matematika dan pembelajaran berbasis kegiatan lesson study. FKIP Matematik.UMB

Widada, W. (2006) Kiat Meningkatkan Kompetensi Matematika MelaluiPengembangan Skema Matematis. Pidato Pengukuhan Guru Besar Bidang Ilmu Pendidikan Matematika Universitas Muhammadiyah Bengkulu.

Widada, W. (2010) Pengembangan Lanjutan Teori dan model Pembelajaran Matematika Berbasis Extended Level Triad++ untuk Mahasiswa Teori Graph. Laporan Hasil Penelitian Hibah Penelitian Kompetensi Tahun Anggaran 2010. Bengkulu; FKIP UNIB.

Widada, W. (2011) Penelitian Pendidikan Matematika. Bengkulu; FKIP UNIB.

Widada, W. (2011) Materi Kajian Psikologi Kognitif Pendidikan Matematika. Bengkulu; FKIP UNIB.

Widada, W. (2011) Model Pembelajaran Berbasis Extended Level Triad ++ Bengkulu; FKIP UNIB.

Widada, W. (2012) Kumpilasi/Kumpulan Artikel Proses Berpikir dan Proses Kognitif dalam Pembelajaran Matematika, Bengkulu; FKIP UNIB.

Widada, W. (2012) Model Pendidikan Karakter melalui Pembelajaran Matematika yang Membumi, Bengkulu; FKIP UNIB.

Widada, W. (2016) Sintak Model pembelajaran Ektended Triad Level ++, Bengkulu; FKIP UNIB 